\title{
Myosin VIIA Is Required for Aminoglycoside Accumulation in Cochlear Hair Cells
}

\author{
G. P. Richardson, ${ }^{1}$ A. Forge, ${ }^{2}$ C. J. Kros, ${ }^{1,3}$ J. Fleming, ${ }^{4}$ S. D. M. Brown, ${ }^{5}$ and K. P. Steel ${ }^{4}$ \\ 1School of Biological Sciences, University of Sussex, Brighton BN1 9QG, United Kingdom, 2Institute of Laryngology and \\ Otology, University College London, London WC1X 8EE, United Kingdom, ${ }^{3}$ Department of Physiology, School of Medical \\ Sciences, University of Bristol, Bristol BS8 1TD, United Kingdom, ${ }^{4}$ Medical Research Council Institute of Hearing \\ Research, Nottingham NG7 2RD, United Kingdom, and ${ }^{5}$ Medical Research Council Mammalian Genetics Unit and Mouse \\ Genome Centre, Oxford OX11 ORD, United Kingdom
}

Myosin VIIA is expressed by sensory hair cells and has a primary structure predicting a role in membrane trafficking and turnover, processes that may underlie the susceptibility of hair cells to aminoglycoside antibiotics. $\left[{ }^{3} \mathrm{H}\right]$ Gentamicin accumulation and the effects of aminoglycosides were therefore examined in cochlear cultures of mice with different missense mutations in the myosin VIIA gene, Myo7a, to see whether myosin VIIA plays a role in aminoglycoside ototoxicity. Hair cells from homozygous mutant $M y o 7 a^{\text {sh1 }}$ mice, with a mutation in a nonconserved region of the myosin VIIA head, respond rapidly to aminoglycoside treatment and accumulate high levels of gentamicin. Hair cells from homozygous mutant Myo7a ${ }^{6 J}$ mice, with a mutation at a highly conserved residue close to the ATP binding site of the myosin VIIA head, do not accumulate $\left[{ }^{3} \mathrm{H}\right]$ gentamicin and are protected from aminoglycoside ototoxicity. Hair cells from heterozygotes of both alleles accumulate $\left[{ }^{3} \mathrm{H}\right]$ gentamicin and respond to aminoglycosides.
Although aminoglycoside uptake is thought to be via apical surface-associated endocytosis, coated pit numbers on the apical membrane of heterozygous and homozygous Myo7a $\mathrm{a}^{6 \mathrm{~J}}$ hair cells are similar. Pulse-chase experiments with cationic ferritin confirm that the apical endocytotic pathway is functional in homozygous Myo7a ${ }^{6 \mathrm{~J}}$ hair cells. Transduction currents can be recorded from both heterozygous and homozygous $M y o 7 a^{6 J}$ hair cells, suggesting it is unlikely that the drug enters via diffusion through the mechanotransducer channel. The results show that myosin VIIA is required for aminoglycoside accumulation in hair cells. Myosin VIIA may transport a putative aminoglycoside receptor to the hair cell surface, indirectly translocate it to sites of membrane retrieval, or retain it in the endocytotic pathway.

Key words: hair cell; aminoglycosides; unconventional myosin; ototoxicity; endocytosis; myosin VIIA
The senses of hearing and balance depend on hair cells present in the sensory epithelia of the inner ear. Hair cells are extremely sensitive transducers, capable of responding to displacements of a few nanometers, and are also very susceptible to both noise- and drug-induced damage. Aminoglycoside antibiotics are one class of drug known to be toxic for sensory hair cells (Hawkins, 1976), and the rapid accumulation of high levels of these drugs in hair cells may be the primary reason for the selective toxicity observed in vivo (Hiel et al., 1992). Aminoglycosides are polycationic, water-soluble compounds and are known to accumulate in lysosomal-like structures in hair cells (de Groot et al., 1990), indicating that they are likely to enter the cell via endocytosis.

Endocytosis is one of many cellular events requiring actindependent membrane motility, and evidence has now been provided that the unconventional type I myosins are involved in this process (Novak et al., 1995; Durrbach et el., 1996; Geli and Reizman, 1996; Jung et al., 1996). The myosin superfamily currently consists of 14 classes of proteins (for review, see Mooseker

Received July 25, 1997; revised Oct. 1, 1997; accepted Oct. 3, 1997.

This work was supported by the Medical Research Council, The Hearing Research Trust, and European Union contract CHRXCT 94-0659. C.J.K. is a Royal Society University Research Fellow. We thank Kevin Legan, Richard Goodyear, and Ian Russell for their helpful criticisms of this manuscript and Cecylia Malenczak, Graham Nevill, Laura Perry, and Julian Thorpe for their invaluable assistance.

Correspondence should be addressed to Dr. Guy P. Richardson, School of Biological Sciences, University of Sussex, Falmer, Brighton BN1 9QG, UK.

Copyright (C) 1997 Society for Neuroscience $0270-6474 / 97 / 179506-14 \$ 05.00 / 0$ and Cheney, 1995; Titus, 1997), and 10 different myosins are expressed in the sacculus of the inner ear of the bullfrog (Solc et al., 1994). Much attention has been focused on the type I myosins, because they are candidates for the adaptation motor thought to control tension in the tip link gating the transducer channels (Gillespie and Hudspeth, 1993; Gillespie et al., 1993; Metcalf et al., 1994; Solc et al., 1994; Walker and Hudspeth, 1996; Yamoah and Gillespie, 1996). Myosins VI and VIIA are two other unconventional myosins expressed by sensory hair cells (Avraham et al., 1995; Hasson et al., 1995; El-Amraoui et al., 1996). Mutations in the mouse myosin VI or mouse myosin VIIA genes lead to deafness and vestibular disorders (Avraham et al., 1995; Gibson et al., 1995) and mutations in the gene encoding human myosin VIIA are responsible for Usher syndrome type $1 \mathrm{~B}$, in which both deafness and blindness occur (Weil et al., 1995). However, as yet, the specific cellular functions of these two unconventional myosins in hair cells are unknown.

In addition to being expressed specifically by the hair cells within the inner ear, both myosin VI (Hasson and Mooseker, 1994) and myosin VIIA (M. Mooseker and T. Hasson, personal communication) are expressed at high levels in kidney proximal tubule cells, a cell type that is the other major target of aminoglycoside toxicity (Kaloyanides and Pastoriza-Munoz, 1980; Cojecel and Hook, 1983). The correspondence between the expression levels of two classes of unconventional myosin and sensitivity to aminoglycoside antibiotics prompted the hypothesis 
that either myosin VI or myosin VIIA, or both proteins, may be involved in some aspect of aminoglycoside ototoxicity. $\left[{ }^{3} \mathrm{H}\right] \mathrm{Gen}$ tamicin accumulation and the effects of aminoglycoside antibiotics were therefore examined in cochlear cultures prepared from mice with two different missense mutations in the head region of the myosin VIIA molecule. One mutation, Myo $7 a^{s h 1}$, is at a nonconserved site (Arg407) lying on the surface of the motor domain, and the other, $M y o 7 a^{6 J}$, is at a highly conserved residue (Arg145) lying close to the ATP binding site (Gibson et al., 1995).

\section{MATERIALS AND METHODS}

Materials. HBSS, Eagle's Minimum Essential Medium, HEPES buffer, neomycin sulfate, gentamicin sulfate, and cationized ferritin were obtained from Sigma (Poole, Dorset, UK). Heat-inactivated horse serum and DMEM were from Life Technologies (Paisley, Scotland). $\left[{ }^{3} \mathrm{H}\right] \mathrm{Gen}-$ tamicin (specific activity, $0.98 \mathrm{mCi} / \mathrm{mmol}$ ) was custom-synthesized by Amersham (Little Chalfont, UK). This preparation ran as three peaks on thin layer chromatograms with mobilities characteristic of the three known isomers (C1, C1a, and C2) of gentamicin. Glutaraldehyde, osmium tetroxide, and Epikote 812 were from TAAB Laboratories (Reading, UK). All other materials were of reagent grade and obtained from either Merck (Poole, Dorset, UK) or Sigma. Mice carrying the spontaneous original shaker-1 mutation $\left(M y o 7 a^{\text {shl }}\right)$ were obtained from Harwell in the $1980 \mathrm{~s}$, and the $f r, p$, and $c^{c h}$ mutations were selectively removed. The stock was back-crossed to the inbred $\mathrm{CBA} / \mathrm{Ca}$ strain and is now maintained as a closed colony. C57BL/6J mice with the spontaneous $M y o 7 a^{6 J}$ mutation were kindly provided by Dr. Wayne Frankel (The Jackson Laboratory, Bar Harbor, ME) on a $25 \%$ BALBc/75\% C57BL/6J background (Letts et al., 1994). The mouse colonies were kept in full accordance with United Kingdom Home Office regulations.

Preparation of cochlear cultures. Organotypic cochlear cultures were prepared from the inner ears of 1-3 d postnatal mice (with the day of birth considered day 0) following procedures described previously (Russell and Richardson, 1987) and grown on collagen-coated glass coverslips in Maximow slide assemblies at $37^{\circ} \mathrm{C}$ for $1 \mathrm{~d}$ before use. The medium contained 95\% Eagle's Minimum Essential Medium in Earle's salts with additional HEPES buffer (10 mM, pH 7.2) and 5\% heat-inactivated horse serum. Each culture contained both cochleae from one mouse pup, and each cochlea was divided into apical and basal segments. The bodies of the mouse pups were frozen after the cochleae had been removed and stored at $-70^{\circ} \mathrm{C}$ for subsequent genotyping. In most cases, pups were obtained from the litters resulting from homozygous $x$ heterozygous matings, although because of breeding problems some of the earlier experiments were done with pups from heterozygous $\times$ heterozygous matings.

Preparation of cultures for scanning electron microscopy. Coverslips with adherent cultures were removed from the Maximow slide assemblies, washed three times in HEPES-buffered (10 mM, pH 7.2) HBSS (HBHBSS) over the course of $10 \mathrm{~min}$, and incubated for $1 \mathrm{hr}$ at room temperature $\left(18-22^{\circ} \mathrm{C}\right)$ in HBHBSS containing $1 \mathrm{~mm}$ neomycin sulfate. At the end of the incubation period, the cultures were washed twice in HBHBSS and fixed in $2.5 \%$ glutaraldehyde in $0.1 \mathrm{~m}$ sodium cacodylate buffer, $\mathrm{pH} 7.2$, for $1 \mathrm{hr}$. The cultures were then washed three times with $0.1 \mathrm{M}$ cacodylate buffer, post-fixed in $1 \%$ osmium tetroxide for $1 \mathrm{hr}$, washed in buffer, dehydrated through a series of ascending concentrations of ethanol, and critical point-dried from liquid $\mathrm{CO}_{2}$. The cultures were mounted on aluminum stubs, sputter-coated with gold, and examined with a Leica (Nussloch, Germany) Leo S420 scanning electron microscope.

Preparation of cultures for light microscopy. The coverslips with adherent cultures were removed from the Maximow slide assemblies, placed in 35 -mm-diameter plastic culture dishes, washed three times with $4 \mathrm{ml}$ of warm $\left(37^{\circ} \mathrm{C}\right) \mathrm{HBHBSS}$, and incubated in HBHBSS containing $2 \mathrm{~mm}$ gentamicin sulfate for $2 \mathrm{hr}$ at $37^{\circ} \mathrm{C}$ in a humid incubator. Cultures were then washed twice with $4 \mathrm{ml}$ of HBHBSS and fixed as described above. After dehydration, cultures were equilibrated with propylene oxide and infiltrated with and embedded in epoxy resin. The resin was cured at $60^{\circ} \mathrm{C}$ for $2 \mathrm{~d}$, and the cultures were sectioned with glass knives at a thickness of $1 \mu \mathrm{m}$ in a plane perpendicular to the collagen substrate. At a minimum, 10 sections were collected at three different levels along each coil. These were stained with $1 \%$ toluidine blue in $1 \%$ borax buffer and examined with a Zeiss IM35 inverted microscope.

Preparation of cultures for freeze fracture microscopy. Cultures were washed briefly with HBHBSS, fixed for $1 \mathrm{hr}$ in $2.5 \%$ glutaraldehyde in 0.1 M sodium cacodylate buffer, infiltrated with $25 \%$ glycerol in the same buffer, sandwiched between two freeze fracture support plates using a yeast in glycerol paste, and frozen in pentane/isopentane (4:1) cooled in liquid nitrogen. Samples were fractured by separating the sandwich and replicated in a Balzer's BAF 400D machine using previously published procedures (Forge, 1991). Replicas were examined and photographed using a Jeol 1200EX2 electron microscope. When necessary, samples were tilted using the goniometer stage so the replicas of the outer hair cell surfaces were as close as possible perpendicular to the electron beam before photography. Only hair cell surfaces on which the entire apical membrane was visible were analyzed. The photographic negative images of the replicas were digitized using a flat bed scanner with a transmitted light adaptor and analyzed with a personal computer-based image analysis system (AnalySIS; Soft Imaging Software GmbH, Münster, Germany). The total numbers of pits (sites of vesicle invagination) on each hair cell apical membrane profile and the area of each membrane profile were estimated from a total of 54 different outer hair cell profiles from nine different replicas.

Autoradiography. Cultures were removed from the Maximow slide assemblies, placed in 35-mm-diameter plastic culture dishes, washed three times with HBHBSS, and then incubated in HBHBSS containing $0.1 \mathrm{~mm}\left[{ }^{3} \mathrm{H}\right]$ gentamicin for $2 \mathrm{hr}$ at $37^{\circ} \mathrm{C}$. Cultures were then placed on ice, washed three times with $4 \mathrm{ml}$ of ice-cold HBHBSS over the course of $10 \mathrm{~min}$, and fixed in cold $2.5 \%$ glutaraldehyde buffered with $0.1 \mathrm{M}$ sodium cacodylate, $\mathrm{pH} 7.2$, for $1 \mathrm{hr}$. Subsequent fixation, dehydration, and plastic embedding steps were performed at room temperature as described above. Unstained, $1-\mu \mathrm{m}$-thick plastic sections mounted on glass slides were coated with Ilford $\mathrm{K} 5$ emulsion diluted with an equal volume of $\mathrm{H}_{2} \mathrm{O}$ and exposed for 2 or 4 weeks. Autoradiographs were developed with Phenisol (1:5 dilution) for 2 min, fixed with Kodak Unifix (1:5 dilution) for $4 \mathrm{~min}$, washed, dried, mounted in Histomount, and viewed by phasecontrast microscopy. To evaluate the temperature dependence of $\left[{ }^{3} \mathrm{H}\right]$ gentamicin uptake, heterozygous $M y o 7 a^{6 J}$ cultures were incubated in $0.1 \mathrm{~mm}\left[{ }^{3} \mathrm{H}\right]$ gentamicin for $2 \mathrm{hr}$ at recorded temperatures of 3,20 , and $37^{\circ} \mathrm{C}$ and then fixed and processed for autoradiography as described above. Slides were exposed for short periods, and the grains overlying outer hair cell profiles were counted. Grain counts were made for 17-18 outer hair cell profiles at each temperature to determine the average number of grains per outer hair cell profile.

Cationic ferritin pulse chase. Cultures were placed in 35-mm-diameter plastic petri dishes on ice, washed three times with ice-cold HEPESbuffered (10 mM, pH 7.2) DMEM, and incubated in the same medium containing $0.1 \mathrm{mg} / \mathrm{ml}$ cationized ferritin for $1 \mathrm{hr}$ at $3^{\circ} \mathrm{C}$. The cultures were then washed three times with cold HEPES-buffered medium and either fixed immediately or incubated at $37^{\circ} \mathrm{C}$ for 1 or $2 \mathrm{hr}$ in a $95 \%$ air $/ 5 \% \mathrm{CO}_{2}$ atmosphere before fixation and embedding in plastic as described above. Ultrathin $(90 \mathrm{~nm})$ sections were cut with a diamond knife, mounted on high-transmission copper grids, stained with uranyl acetate and lead citrate, and viewed with a Hitachi 7100 transmission electron microscope.

Electrophysiology. Experimental techniques for recording mechanoelectrical transducer currents from outer hair cells in organotypic cultures were largely as described before (Kros et al., 1992; Géléoc et al., 1997). The salts in the extracellular solution were (in $\mathrm{mM}$ ): $137 \mathrm{NaCl}, 0.7$ $\mathrm{NaH}_{2} \mathrm{PO}_{4}, 5.8 \mathrm{KCl}, 1.3 \mathrm{CaCl}_{2}, 0.9 \mathrm{MgCl}_{2}$, and 10 HEPES-NaOH, $\mathrm{pH}$ 7.5. Patch pipettes were filled with (in mM): $145 \mathrm{CsCl}, 1.0$ EGTA-NaOH, $3 \mathrm{MgCl}_{2}, 5 \mathrm{Na}_{2} \mathrm{ATP}$, and 5 HEPES-NaOH, $\mathrm{pH}$ 7.3. Transducer currents were elicited by applying $45 \mathrm{~Hz}$ sinusoidal force stimuli to the apical surfaces of the hair cells by means of a fluid jet.

Genotyping. Mice were genotyped by PCR and subsequent enzyme digestion. For the $M y o 7^{6 J}$ mutation the primers GACAACTCTAGCCGCTTTGG and AGTGTGCTAACAGATGGCCC were used. The PCR buffer contained $2 \mathrm{~mm} \mathrm{Mg}^{2+}$, and the annealing temperature was $57^{\circ} \mathrm{C}$. PCR products were digested with $A f I I I$, giving a 190 bp product in the homozygous mutants and 190,99 , and $91 \mathrm{bp}$ products in heterozygous littermates. The original Myo $7 a^{s h 1}$ mutation was detected using primers CTGACAACCAGGAAGCACTG and ATCGATGAGGGAGATGACG with $1 \mathrm{~mm} \mathrm{Mg}^{2+}$ and an annealing temperature of $51^{\circ} \mathrm{C}$. PCR products were digested with $M s p$ I to give a 65 bp product in homozygous mutants and 65,37 , and 28 bp products in the heterozygous controls.

\section{RESULTS}

Two different methods and two different compounds, neomycin and gentamicin, were used to assess the sensitivity of mutant hair 
cells to aminoglycoside antibiotics. Both neomycin and gentamicin are highly ototoxic and have similar effects on hair cells in vitro (Kotecha and Richardson, 1994). The first method involves treating the cultures with neomycin for $1 \mathrm{hr}$ at room temperature and then uses scanning electron microscopy to examine the surface of the organ of Corti. This treatment results in the formation of numerous large, membrane-filled blebs on the apical surface of hair cells (Richardson and Russell, 1991) and has been suggested to result from an effect of the drug on the early endosomal or recycling compartment of the endocytotic pathway (Forge and Richardson, 1993). With the second method, cultures are treated with gentamicin for $2 \mathrm{hr}$ at $37^{\circ} \mathrm{C}$, and then, after fixation, embedding, and sectioning, the hair cells are examined by light microscopy. The surface effects elicited at $20^{\circ} \mathrm{C}$ are not seen at $37^{\circ} \mathrm{C}$, but instead a number of symptoms characteristic of hair cell death, ranging from the marginal clumping of the chromatin around the nuclear envelope to the appearance of cells with pyknotic nuclei and densely stained cytoplasm, are observed. With both of these methods, there are differential effects along the length of the cochlea, and hair cells at the apical ends of apical-coil cultures do not respond, whereas effects are always observed in the basal coils. Inner hair cells were excluded from this study, because they tend to respond less vigorously and are not always visible in scanning electron micrographs as they are covered by the tectorial membrane. Consequently, analysis was restricted to outer hair cells in basal coil cultures.

\section{Morphological and physiological characteristics of outer hair cells in Myo7a ${ }^{6 J}$ cultures}

The morphology of outer hair cells in basal-coil cultures prepared from $M y o 7 a^{6 J}$ mice is presented in Figures 1 and 2. In cultures from heterozygous control (Fig. 1a) and homozygous mutant (Fig. $1 b)$ mice, the shape and form of the outer hair cell bodies and the distribution of intracellular organelles within them are very similar. However, whereas well defined stereocilia bundles can be observed on the apical surface of the outer hair cells in the heterozygous cultures (Fig. 1a), the apical surface of the homozygous $M y o 7 a^{6 J}$ outer hair cells sometimes bulges outward, and the stereocilia always project from it at various angles (Fig. 1b). The disorganized nature of the hair bundles in cultures prepared from the homozygous Myo7a $a^{6 J}$ mice is readily apparent in scanning electron micrographs of the surface of the organ of Corti (Fig. 2). As a result of this difference in apical surface structure, living cultures prepared from homozygous mutant $M y o 7 a^{6 J}$ mice can be readily distinguished from those prepared from either heterozygous or wild type litter mates using Normaski optics. Cultures of $M y o 7 a^{6 J}$ mice can therefore be morphologically phenotyped before use, although classification was always confirmed by subsequent genotypic analysis.

Electrophysiological data were obtained from three outer hair cells in heterozygous $M y o 7 a^{6 J}$ cultures and from four in homozygous $M y o 7 a^{6 J}$ cultures. Under patch clamp in the whole-cell configuration, outer hair cells from both heterozygous control and homozygous mutant $M y o 7 a^{6 J}$ cultures have a linear leak conductance of $<1 \mathrm{nS}$ at a holding potential of $-84 \mathrm{mV}$, indicating they are in good physiological condition. Furthermore, mechanotransducer currents of $>700 \mathrm{pA}$ in size, comparable to those previously reported from cultures prepared from Swiss CD1 mice (Kros et al., 1992; Géléoc et al., 1997), can be recorded from outer hair cells in both heterozygous and homozygous $M y o 7 a^{6 J}$ cultures (Fig. 3). Differences between the shape of the current responses in heterozygous and homozygous mutants may be attributable to the disorganization of the hair bundles in the latter.

\section{Effects of aminoglycosides on hair cells in Myo7a ${ }^{6 J}$ cultures}

In total, 10 heterozygous and 6 homozygous saline-treated Myo $7 a^{6 J}$ basal-coil cultures, along with 12 heterozygous and 8 homozygous neomycin-treated Myo $7 a^{6 J}$ basal-coil cultures, were examined by scanning electron microscopy. The sensory hair cells in heterozygous $M y o 7 a^{6 J}$ cultures develop numerous large blisters or blebs on their apical surfaces during treatment with $1 \mathrm{~mm}$ neomycin for $1 \mathrm{hr}$ at room temperature (Fig. $4 a$ ). The largest and most prominent of these blisters tend to form around the base of the kinocilium, but they also develop at several other locations around the perimeter of the hair cell surface. In contrast, neomycin treatment has little effect on the apical surface of hair cells in the homozygous mutant $M y o 7 a^{6 J}$ cultures (Fig. 4b). Two neomycin-treated wild type controls were also included in this part of the study, and the hair cells reacted in a manner identical to those in the heterozygous cultures.

In total, 8 heterozygous and 10 homozygous saline-treated $M y o 7 a^{6 J}$ basal-coil cultures, along with 8 heterozygous and 15 homozygous gentamicin-treated $M y o 7 a^{6 J}$ basal-coil cultures, were examined by light microscopy. In cultures prepared from heterozygous $M y o 7 a^{6 J}$ mice that have been treated with $2 \mathrm{~mm}$ gentamicin for $2 \mathrm{hr}$ at $37^{\circ} \mathrm{C}$, several signs of hair cell damage can be observed in the drug-treated cultures (Fig. $5 c$ ), in contrast to the saline-treated controls (Fig. 5a). Degenerating hair cells with dense, basophilic cytoplasm and pyknotic nuclei that appear to be in the process of being expelled from the epithelium can be observed, along with hair cells that appear to be lysing and those with nuclei containing marginally clumped chromatin (Fig. 5c). Some of these features are characteristic of hair cells undergoing apoptotic cell death (Forge, 1985; Li et al., 1995). In cultures prepared from homozygous $M y o 7 a^{6 J}$ mutants that have undergone the same drug treatment, morphological changes are not observed (Fig. $5 d$ ), and the hair cells are indistinguishable from those in saline-treated, homozygous mutant cultures (Figs. 5b).

\section{[ ${ }^{3} \mathrm{H}$ ]Gentamicin accumulation in Myo7a ${ }^{6 J}$ cultures}

Accumulation of aminoglycosides was examined with autoradiographs prepared from cultures that had been incubated in saline containing $0.1 \mathrm{~mm}\left[{ }^{3} \mathrm{H}\right]$ gentamicin for $2 \mathrm{hr}$ at $37^{\circ} \mathrm{C}$. In total, 19 heterozygous and 13 homozygous $M y o 7 a^{6 J}$ basal-coil cultures were examined with this technique. Although gentamicin has no morphological effect on hair cells at this concentration, selective accumulation of $\left[{ }^{3} \mathrm{H}\right]$ gentamicin is evident in hair cells in cultures prepared from heterozygous Myo7a $a^{6 J}$ mice (Fig. 6a) but not in cultures from homozygous $M y o 7 a^{6 J}$ mutant mice (Fig. 6b). In the cultures from heterozygous $M y o 7 a^{6 J}$ mice, both the inner and outer hair cells are heavily labeled relative to the uniform background observed overlying the surrounding supporting cells, the cells of the greater epithelial ridge, the connective tissue, and underlying collagen substrate (Fig. 6a). Inner hair cells in basalcoil cultures are sometimes less heavily labeled than the outer hair cells. Accumulation of $\left[{ }^{3} \mathrm{H}\right]$ gentamicin in heterozygous cultures was also found to be strongly temperature-dependent. Four basal-coil cultures were examined at each temperature, and examples of hair cell labeling observed after incubation at 3,20, and $37^{\circ} \mathrm{C}$ are shown in Figure $7 a-c$. The average number of grains overlying each outer hair cell profile is plotted as a function of 

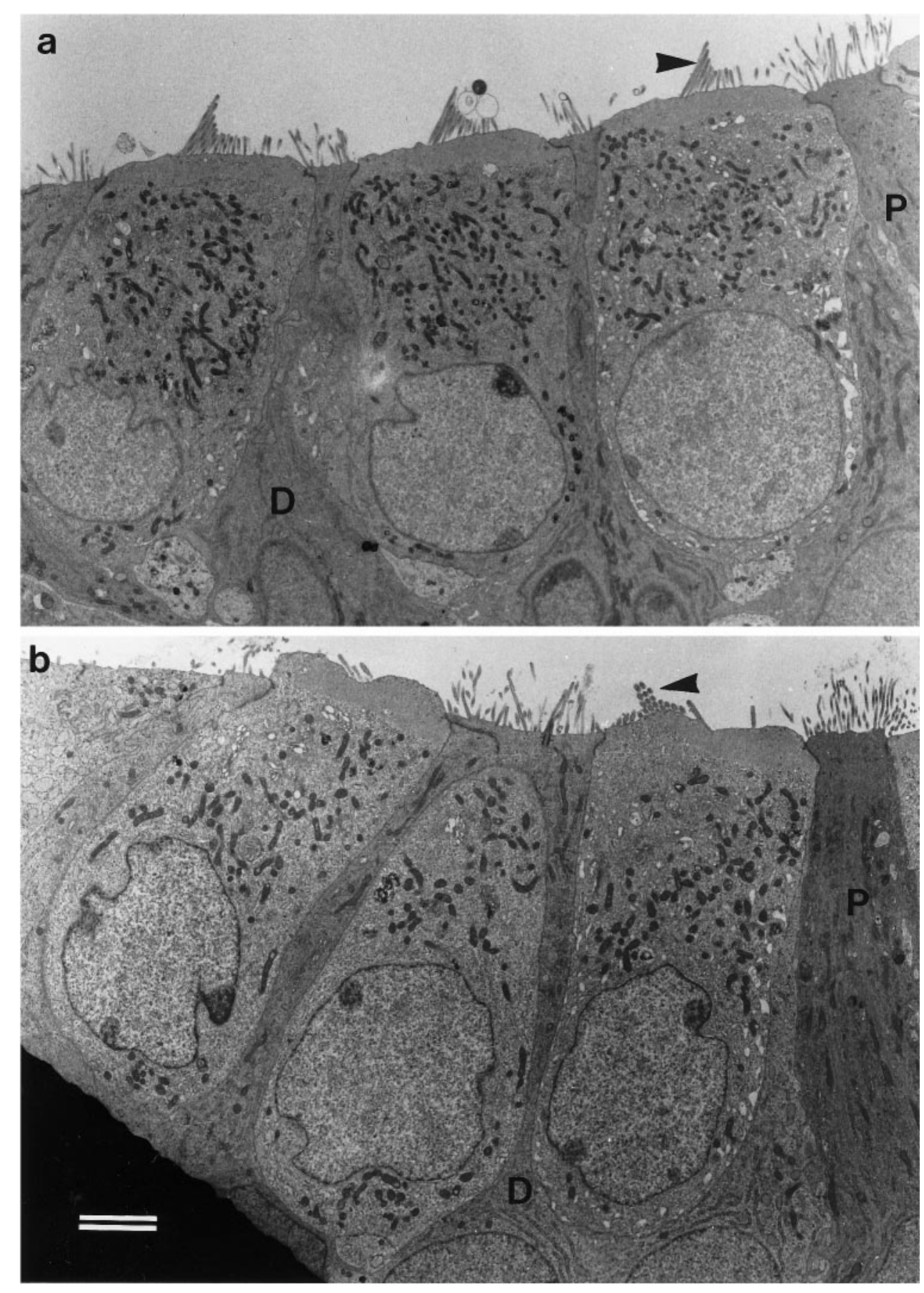

Figure 1. Transmission electron micrographs of basal-coil outer hair cells in the organ of Corti in cultures from heterozygous $(a)$ and homozygous $(b)$ Myo $7 a^{6 J}$ mice. The profiles of three outer hair cell bodies can be observed in both $a$ and $b$, which are flanked by the darker staining processes of the immature Deiters' $(D)$ and pillar $(P)$ cells. The arrowheads indicate the stereocilia bundles on the first row outer hair cells. Scale bar, $2 \mu \mathrm{m}$.

temperature in Figure $7 d$. The curve fitted is equivalent to the Arrhenius equation (Moore, 1972) and indicates the $Q_{10^{\circ} \mathrm{C}}$ is 1.9 between 20 and $30^{\circ} \mathrm{C}$, too steep to attribute the observed accumulation of gentamicin in hair cells to diffusion through a channel.

\section{Apical surface endocytosis in $M y 07 a^{6 J}$ cultures}

Previous studies have shown there is a correlation between the number of endocytotic vesicles associated with the apical surface of hair cells and their sensitivity to neomycin (Forge and Richardson 1993). A freeze fracture method was therefore used to determine the number and density of these vesicles associated with the surfaces of hair cells in $M y o 7 a^{6 J}$ cultures. Pits corresponding to endocytotic vesicles in the process of forming on the apical surface are readily apparent in fracture replicas of the surfaces of outer hair cells in cultures from both heterozygous and homozygous Myo $7 a^{6 J}$ mice (Fig. $8 a, b$ ). These pits are also observed in thin sections (Fig. $8 c, d$ ). They all appear to be coated and are therefore considered endocytotic. Quantitative analysis based on fracture profiles in which the entire apical surface of each hair cell was visible indicates the numbers of coated pits on 

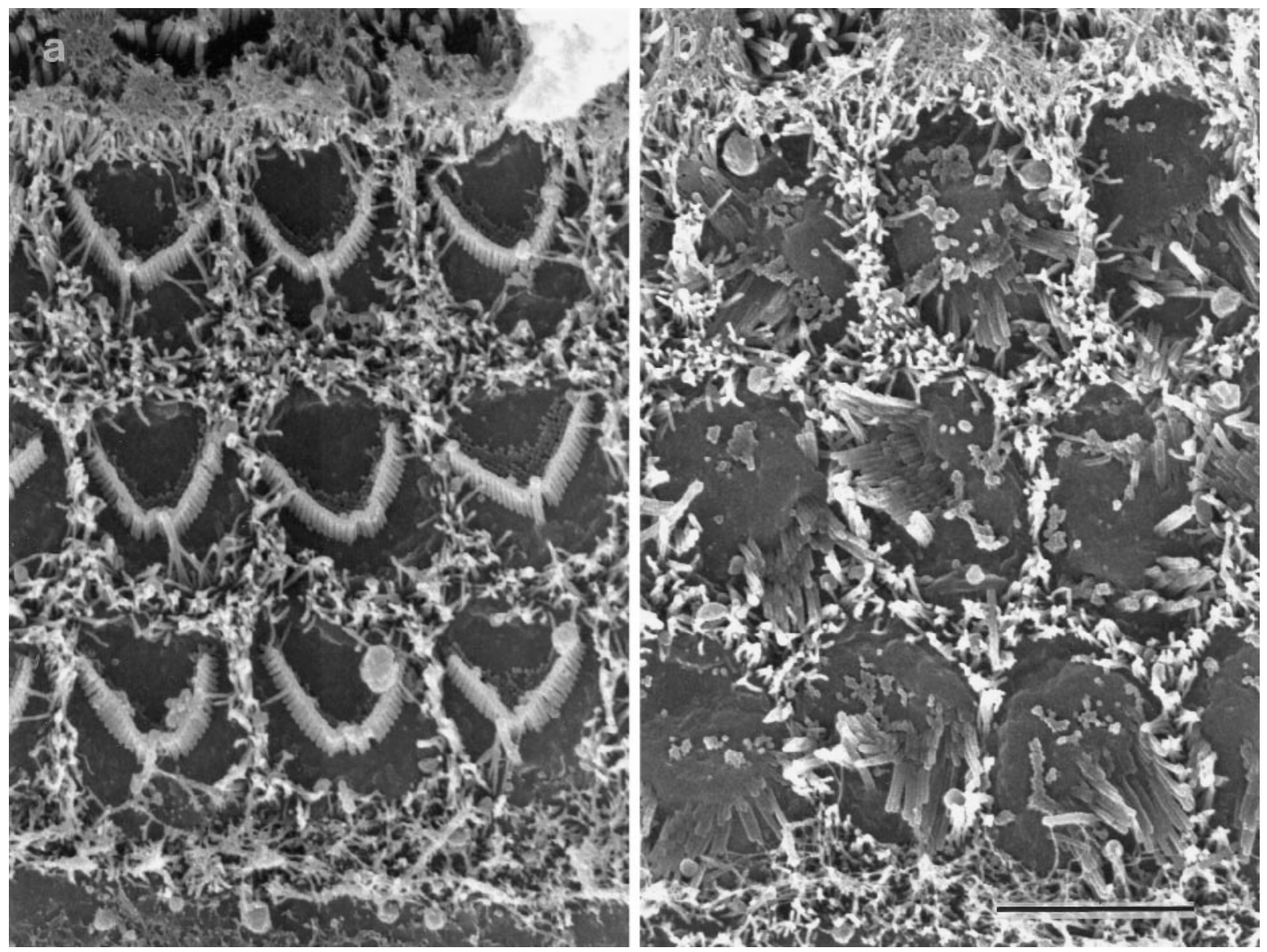

Figure 2. Scanning electron micrographs of the apical surfaces of basal-coil outer hair cells in the organ of Corti in cultures from heterozygous ( $a$ ) and homozygous $(b) M y o 7 a^{6 J}$ mice. In $a$, three rows of well organized, V-shaped stereocilia bundles are observed surrounded by supporting cell microvilli. In $b$, the hair cell surfaces are larger and, the stereocilia bundles are disorganized. Scale bar, $5 \mu \mathrm{m}$.

a

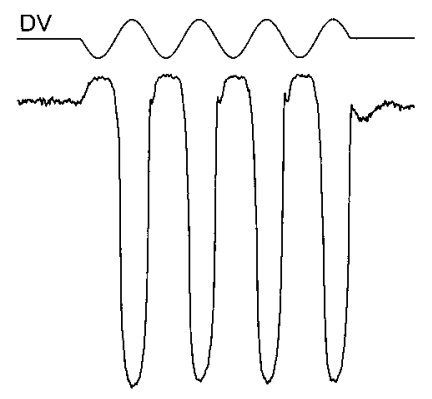

b

Myo7a $a^{6 j} / M^{2} 07 a^{6 j}$

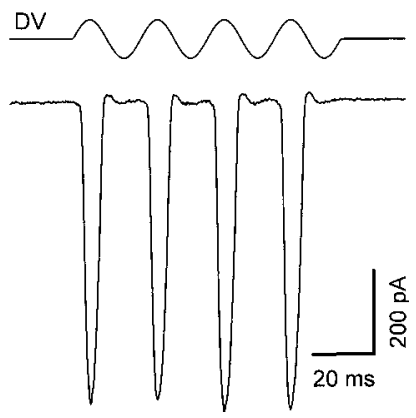

Figure 3. Transducer currents recorded from outer hair cells in cultures prepared from heterozygous $(a)$ and homozygous $(b) M y o 7 a^{6 J}$ mice. Currents were recorded in response to $45 \mathrm{~Hz}$ sinusoidal force stimuli at a holding potential of $-84 \mathrm{mV}$. The driver voltage signal ( $D V$; amplitude, $45 \mathrm{~V})$ to the fluid jet is shown above each current record. Positive deflections are excitatory. Responses are averages of four $(a)$ and five $(b)$ repetitions. Recordings were made at $22^{\circ} \mathrm{C}$.

both mutant and nonmutant $M y o 7 a^{6 J}$ hair cells are the same (Table 1). This analysis further indicates that the apical surface area of outer hair cells is larger in the homozygous mutants than it is in the heterozygotes, as suggested by the scanning electron microscopy. As a result of this increase in surface area, the density of pits per unit area of membrane is $20 \%$ lower in the homozygous mutant cells than it is in the heterozygous cells.

Pulse-chase with cationic ferritin was used to determine whether the endocytotic pathway was functional in the homozygous $M y o 7 a^{6 J}$ cultures. After the initial $1 \mathrm{hr}$ labeling step at $3^{\circ} \mathrm{C}$, cationic ferritin is densely and uniformly distributed over the apical membrane of the hair cells on both the stereociliary and nonstereociliary surfaces, and no intracellular labeling is evident (data not shown). No differences are observed in the distribution of cationic ferritin within heterozygous control and homozygous mutant hair cells at either the 1 or $2 \mathrm{hr}$ chase point. At these times, a considerable amount of cationized ferritin is detected in vesicular and tubular elements lying beneath the apical membrane (Fig. 9a,b). Cationized ferritin is also found in multivesicular bodies and other membrane-containing structures, which may possibly be late endosomes. These are found throughout the cytoplasm down to the level of the nucleus in the hair cells of cultures from both heterozygous and homozygous $M y o 7 a^{6 J}$ mice (Fig. 9c,d).

\section{$\left[{ }^{3} \mathrm{H}\right]$ Gentamicin accumulation and the effects of aminoglycosides in Myo7a ${ }^{\text {sh1 }}$ cultures}

The morphological effects of neomycin and gentamicin and the accumulation of $\left[{ }^{3} \mathrm{H}\right]$ gentamicin were also examined in cultures prepared from the original shaker mutant, $M y o 7 a^{\text {sh } 1}$. In common with hair cells from homozygous $M y o 7 a^{6 J}$ mice, hair cells from $M y o 7 a^{s h 1}$ mice transduce (not shown), but in contrast the hair bundles of homozygous $M y o 7 a^{s h 1}$ mice are highly organized and indistinguishable from those of heterozygous controls. In total, 

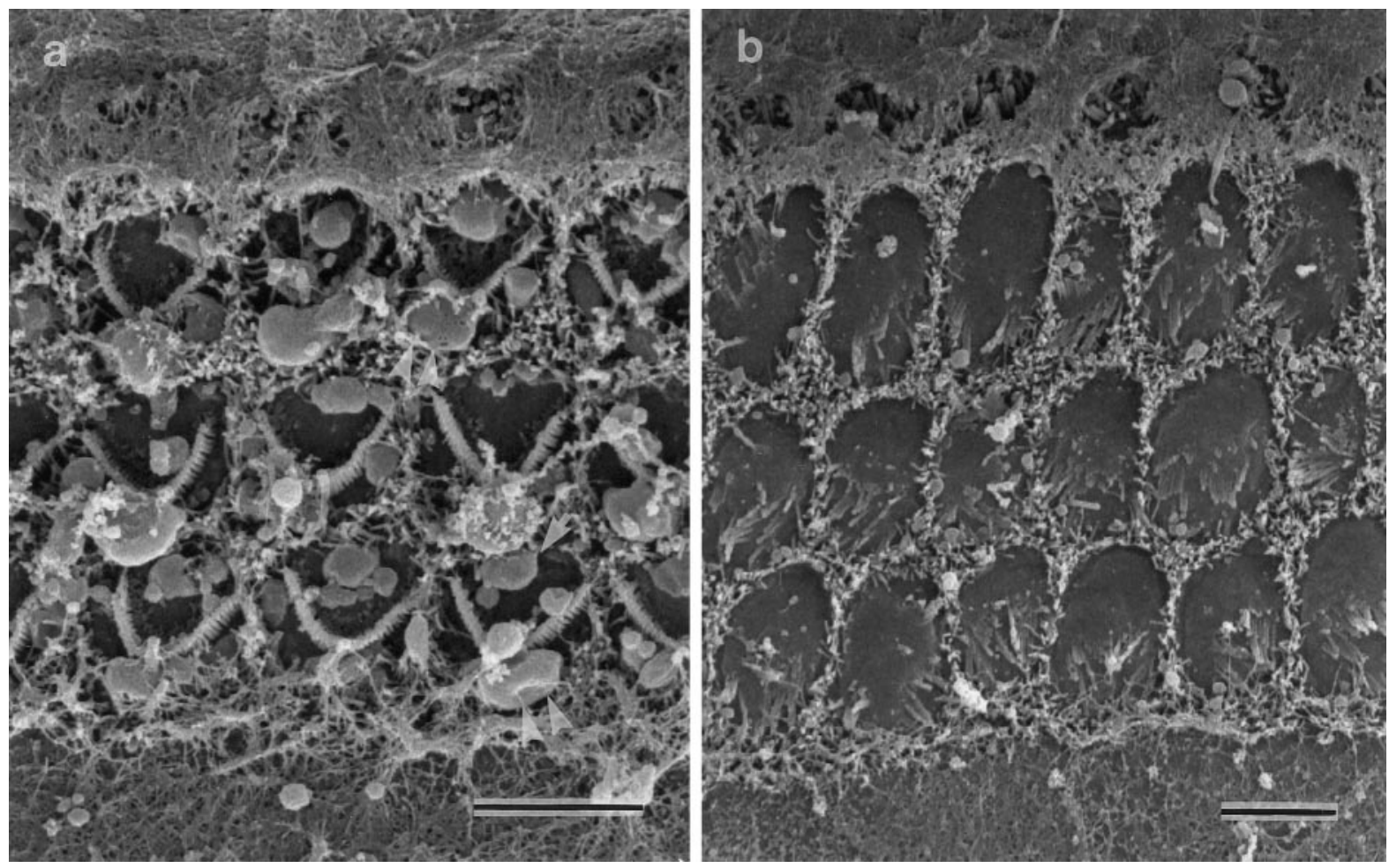

Figure 4. Scanning electron micrographs of the apical surfaces of basal-coil outer hair cells in the organ of Corti of cultures from heterozygous ( $a$ ) and homozygous $(b) M y o 7 a^{6 J}$ mice that have been incubated in HBHBSS containing 1 mu neomycin sulfate for $1 \mathrm{hr}$ at room temperature. In $a$, note the large blisters in the vicinity of the kinocilium (double arrowheads) and the smaller blebs (single arrows) around the perimeter of each hair cell. The apical surface of the hair cells in $b$ is larger but shows little damage. Scale bars, $5 \mu \mathrm{m}$.

six heterozygous and six homozygous neomycin-treated $M y o 7 a^{\text {sh } 1}$ basal coil cultures were examined by scanning electron microscopy. Neomycin has a similar effect on hair cells in both heterozygous and homozygous Myo7a $a^{\text {sh } 1}$ cultures (Fig. 10a,b). Two heterozygous and 2 homozygous saline-treated $M y o 7 a^{s h 1}$ basal-coil cultures, along with 17 heterozygous and 8 homozygous gentamicin-treated Myo $7 a^{\text {shl }}$ basal-coil cultures, were examined by light microscopy. The effects of gentamicin at $37^{\circ} \mathrm{C}$ on heterozygous and homozygous Myo7a $a^{\text {sh } 1}$ cultures are similar (Figs. $10 c, d)$. Both the heterozygous control and the homozygous mutant $M y o 7 a^{s h 1}$ cultures display an ototoxic response to the two aminoglycoside treatment regimens. $\left[{ }^{3} \mathrm{H}\right]$ Gentamicin accumulation was studied with four heterozygous and eight homozygous Myo $7 a^{\text {sh1 }}$ basal-coil cultures. $\left[{ }^{3} \mathrm{H}\right]$ Gentamicin accumulation is evident in hair cells of both heterozygous and homozygous $M y o 7 a^{\text {sh1 }}$ cultures (Fig. 10e,f).

\section{DISCUSSION}

The results show that the hair cells of early postnatal mutant $M y o 7 a^{6 J}$ mice, which have disorganized hair bundles but are otherwise morphologically normal and able to transduce, do not accumulate $\left[{ }^{3} \mathrm{H}\right]$ gentamicin and are largely protected from the ototoxic effects of aminoglycoside antibiotics. Hair cells from early postnatal mutant $M y o 7 a^{\text {sh } 1}$ mice accumulate high levels of $\left[{ }^{3} \mathrm{H}\right]$ gentamicin and respond rapidly to aminoglycoside treatment, as do hair cells from mice heterozygous for either allele. The $M y o 7 a^{s h 1}$ mutation has little effect on the amount of myosin VIIA protein that is expressed, whereas the $M y o 7 a^{6 J}$ mutation leads to an $80 \%$ decrease in the level of expression (Hasson et al., 1997b). Whether the failure to accumulate gentamicin and insensitivity to aminoglycoside treatment in the $M y o 7 a^{6 J}$ hair cells is attributable to the mutation at a site predicted to affect the motor function of myosin VIIA or the reduced level of protein is therefore debatable. Nevertheless, the results clearly show that myosin VIIA is required for aminoglycoside accumulation in hair cells and raise a number of questions about how and where it is involved in this process.

\section{Myosin VIIA structure and distribution suggest a role in apical membrane turnover}

The derived amino acid sequences for both human (Chen et al., 1996; Weil et al., 1996) and mouse (Mburu et al., 1997) myosin VIIA indicate that it is a large protein of $\sim 250 \mathrm{kDa}$ with a typical myosin head and a long tail. This tail contains a short region that may enable the molecule to dimerize via the formation of a coiled coil structure and two large repeats each with a myosin tail homology domain (MyTh 4), similar to regions found in other myosin tails, and a region with similarity to the membraneassociated regions of the band 4.1 family of proteins. Recent immunohistochemical data (Hasson et al., 1997a) have shown that myosin VIIA, along with myosin $\mathrm{I} \beta$ and myosin VI, is concentrated in a largely actin-free zone running around the perimeter of the cuticular plate at the apical end of hair cells in the bullfrog sacculus. This zone contains a large number of vesicles and has been called the pericuticular necklace (Hasson et al., 1997a). It is also a region of the hair cell where microtubules are concentrated in both mammalian (Steyger et al., 1989) and frog hair cells (Jaeger et al., 1994). These observations on the structure and distribution of myosin VIIA suggest that it may mediate some aspect of membrane trafficking at the apical pole of the hair cell. 

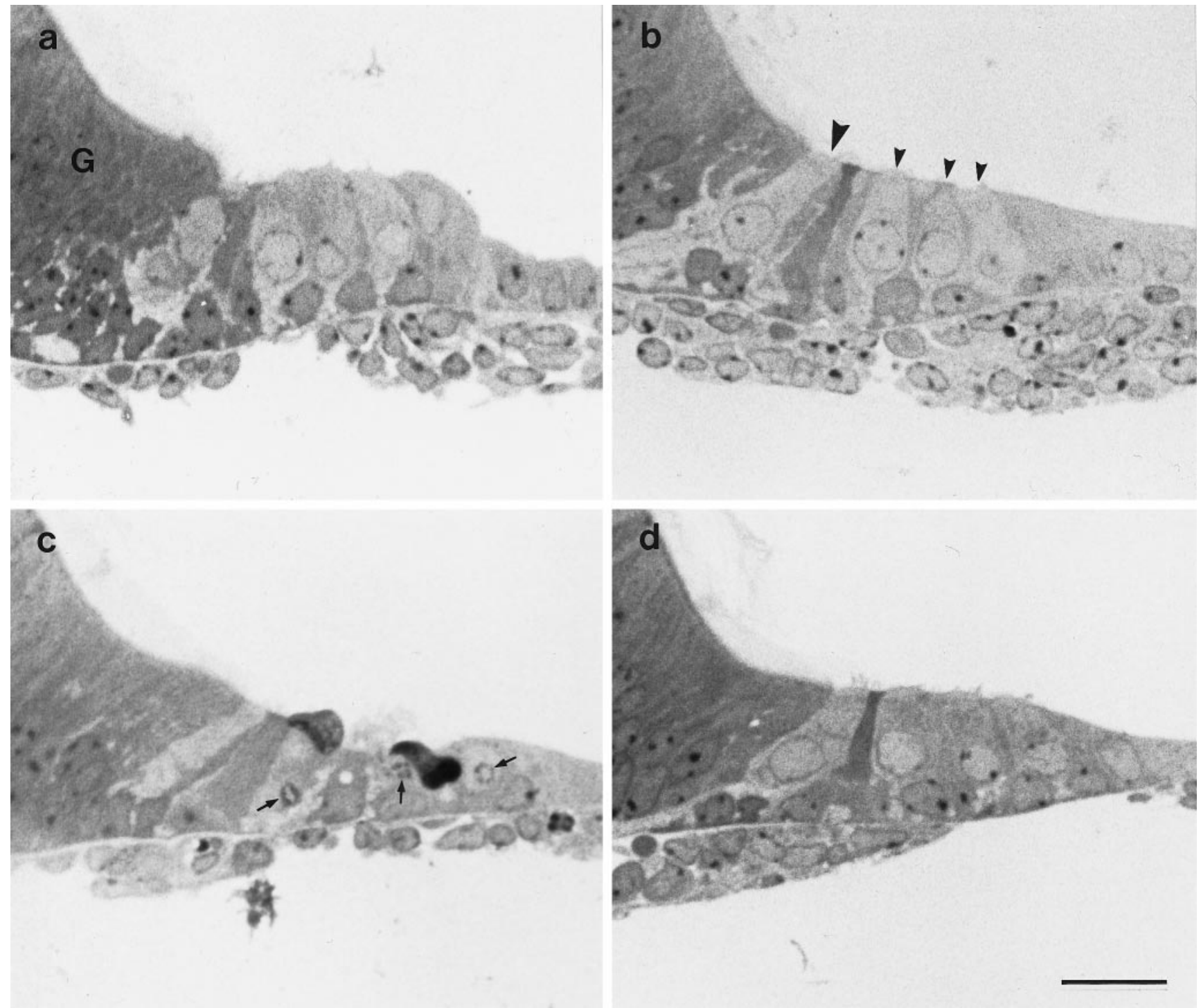

Figure 5. Toluidine blue-stained semithin sections of basal-coil cultures from heterozygous $(a, c)$ and homozygous $(b, d) M y o 7 a^{6 J}$ mice that have been incubated in either HBHBSS $(a, b)$ or HBHBSS containing $2 \mathrm{~mm}$ gentamicin sulfate $(c, d)$ for $2 \mathrm{hr}$ at $37^{\circ} \mathrm{C}$. In $b$, the large arrowhead points to the single inner hair cell, and the smaller arrowheads point to the 3 outer hair cells. In $a$, $G$ indicates the greater epithelial ridge. In $c$, the small arrows point to nuclei with condensed chromatin. Scale bar, $50 \mu \mathrm{m}$.

\section{Evidence for apical surface uptake of aminoglycosides}

The mechanism and route of aminoglycoside entry into hair cells have not been determined definitively, but the available evidence implies it may be via apical surface-associated endocytosis. Aminoglycosides are known to accumulate in lysosomal structures within hair cells in vivo (de Groot et al., 1990), as they do in kidney proximal tubule cells (Silverblatt and Kuehn, 1979; Silverblatt, 1982; Beauchamp et al., 1991), and in the guinea-pig crista ampullaris, aminoglycoside uptake operates against a concentration gradient and is temperature-sensitive and linear over a wide range of concentrations (Williams et al., 1987). The lysosomes that accumulate in vivo in response to aminoglycoside treatment are found just beneath the cuticular plate at the apical end of the hair cell (Darrouzet and Guilhaume, 1974), as are membranebound vacuoles containing gentamicin after short-term gentamicin treatment in vitro (Hashino and Shero, 1995). Also, hair cells at the distal end of apical-coil cochlear cultures, which are virtually unreactive to neomycin treatment, have eight times fewer coated pits associated with their apical surface than the highly responsive basal-coil hair cells (Forge and Richardson, 1993). Overall, these observations would be compatible with aminoglycoside uptake being via either fluid-phase or receptor-mediated endocytosis at the apical surface of the hair cell.

However, whereas all the evidence points toward myosin VIIA being involved in the apical surface-associated endocytosis of aminoglycosides, the results of this study indicate that there is not a simple correlation between the amount of apical surface endocytotic activity, as judged by coated pit numbers per apical surface, and sensitivity to aminoglycoside treatment in $M y o 7 a^{6 J}$ cultures. Furthermore, the results of the cationized ferritin pulsechase experiments show that the apical surface endocytotic pathway is functional in the homozygous $M y o 7 a^{6 J}$ mutants, at least for the cell surface receptors to which the ferritin is bound. This latter result is surprising in view of the fact that cationic ferritin and gentamicin have been shown to co-localize within the same membrane-bound compartment in hair cells in vitro after the 

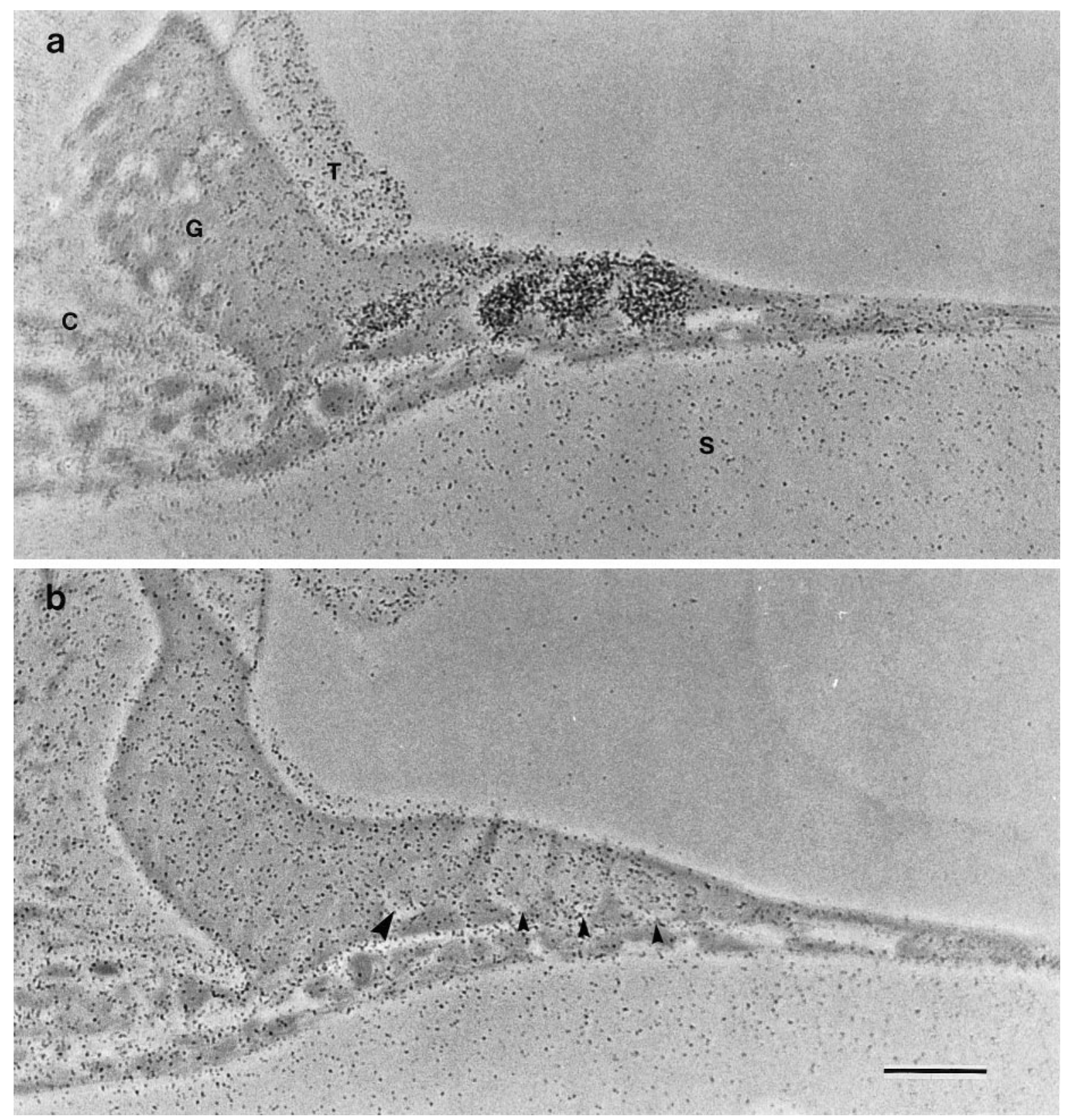

Figure 6. Autoradiographs of sections from basal-coil cochlear cultures prepared from heterozygous $(a)$ and homozygous $(b) M y o 7 a^{6 J}$ mice that have been labeled with $0.1 \mathrm{~mm}\left[{ }^{3} \mathrm{H}\right]$ gentamicin for $2 \mathrm{hr}$ at $37^{\circ} \mathrm{C}$. $C$, Connective tissue; $G$, greater epithelial ridge; $T$, tectorial membrane; $S$, collagen substrate (in $a$ ). In $b$, the large arrowhead points to the basal pole of the inner hair cell, and the small arrowheads point to those of the three outer hair cells. Scale bar, $50 \mu \mathrm{m}$.

simultaneous exposure of the chicken basilar papilla to both compounds (Hashino and Shero, 1995), and it indicates that either apical surface endocytosis is not the route of aminoglycoside uptake or that myosin VIIA is involved in a more subtle aspect of this process.

\section{Aminoglycosides are unlikely to diffuse through the transducer channel}

One alternative pathway for aminoglycoside entry may be through the transducer channel. Aminoglycoside antibiotics are known to block mechanotransduction (Wersäll and Flock, 1964; Kroese and van den Berken, 1980; Kroese et al., 1989; Kössl et al., $1990)$, and, although somewhat large $(\sim 1.0 \mathrm{~nm})$ relative to the estimated pore size of the channel $(0.7 \mathrm{~nm})$, they may be able to diff use through the transduction channel (Kroese et al., 1989). However, hair cells in both heterozygous controls and homozygous $M y o 7 a^{6 J}$ mutants transduce, whereas only those in the homozygous $M y o 7 a^{6 J}$ mutants fail to accumulate and to respond to aminoglycosides, and it is therefore unlikely that the transduction channel is the route of drug entry. The strong temperature dependence of aminoglycoside uptake $\left(Q_{10^{\circ} \mathrm{C}}\right.$ of 1.9 between 20 and $30^{\circ} \mathrm{C}$ ) also makes it unlikely that the observed accumulation of gentamicin in hair cells is attributable to diffusion through the transducer channel, a process expected to have a $Q_{10^{\circ} \mathrm{C}}$ of $\sim 1.3$ (Holton and Hudspeth, 1986), the value for aqueous diffusion (Hille, 1992).

Clathrin-independent endocytotic mechanisms (Hansen et al., 

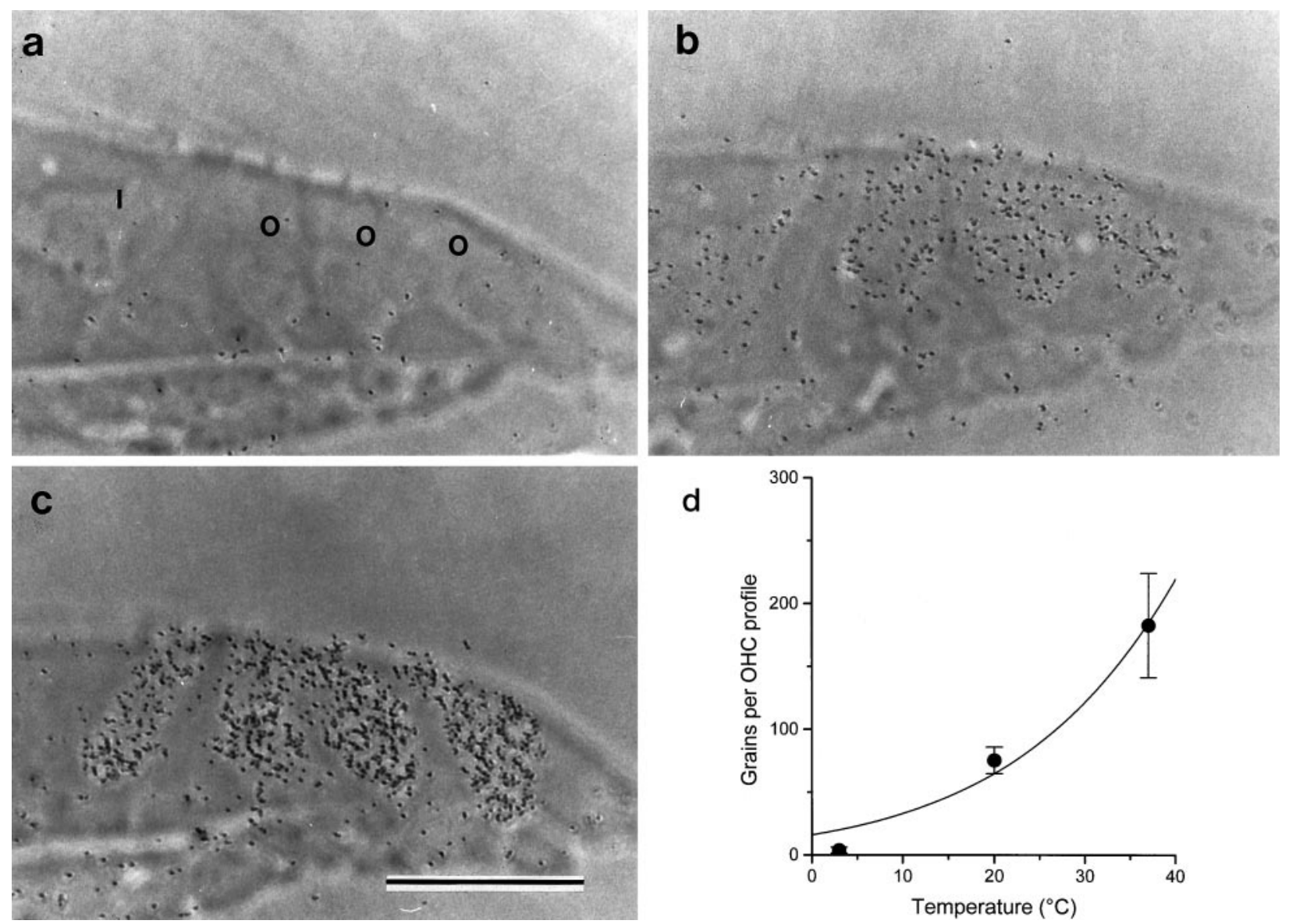

Figure 7. Autoradiographs of basal-coil cochlear hair cells in heterozygous $M y o 7 a^{6 J}$ cultures labeled with $0.1 \mathrm{~mm}\left[{ }^{3} \mathrm{H}\right] \mathrm{gentamicin}$ for $2 \mathrm{hr}$ at $3^{\circ} \mathrm{C}(a)$, $20^{\circ} \mathrm{C}(b)$, and $37^{\circ} \mathrm{C}(c) . I$, Inner hair cell; $O$, outer hair cell (in $\left.a\right)$. Scale bar, $50 \mu \mathrm{m}$. The average numbers of grains $\left( \pm \mathrm{SD} ; n=18\right.$ at 3 and $20^{\circ} \mathrm{C} ; n=$ 17 at $\left.37^{\circ} \mathrm{C}\right)$ per hair cell profile at each temperature are shown in $d$. The fitted curve is of the form $N=A \exp (B /(t+273))$, where $N$ is the number of grains, $t$ is the temperature in degrees Celsius, and $A\left(1.30 \times 10^{10}\right)$ and $B\left(-5602^{\circ} \mathrm{C}\right)$ are constants.

1991; Subtil et al., 1994) (for review, see Sandvig and van Deurs, 1994; Lamaze and Schmid, 1995; Mellman, 1996) can be considered as an alternative uptake pathway for aminoglycosides. However, only pits with distinctive coats (which are presumably clathrin) have been observed associated with the apical surface of the hair cell, and there is no ultrastructural evidence for any other uptake mechanism operating at this site. Although basolateral endocytosis can also be considered as another possible route of uptake, most of the available evidence, as discussed above, favors an apical path, and the levels of endocytotic activity around the basolateral surfaces of hair cells in these cochlear cultures are low. Furthermore, preliminary data (A. Forge and G. P. Richardson, unpublished observations) suggest there is no difference between homozygous $M y o 7 a^{6 J}$ mutants and heterozygous controls in the density of basolateral surface-associated coated pits.

\section{Mechanisms by which myosin VIIA may be required for aminoglycoside accumulation}

Coated pit numbers are the same on the apical surfaces of heterozygous and homozygous $M y o 7 a^{6 J}$ hair cells, whereas only the homozygous $M y o 7 a^{6 J}$ mutants fail to accumulate $\left[{ }^{3} \mathrm{H}\right]$ gentamicin. This indicates that aminoglycoside uptake does not occur via fluid phase endocytosis at this site. Assuming there is a "specific" receptor for aminoglycosides, or at least one with which cationic ferritin does not interact, three hypotheses can be pro- posed for why gentamicin does not accumulate via the apical surface of homozygous mutant $M y o 7 a^{6 J}$ hair cells.

First, myosin VIIA may be required to transport newly synthesized aminoglycoside receptors from sites of production to the cell surface. In the absence of these receptors there would be neither uptake nor accumulation of aminoglycosides.

Second, the putative aminoglycoside receptor may be preferentially located on the stereociliary surfaces, and the continuous, actin-based translocation of myosin VIIA-associated molecules up to the distal tips of the stereocilia may indirectly displace these receptors down the stereocilia to sites of membrane retrieval. Coated pits are not associated with the surfaces of the stereocilia; they are found only around their bases and at other sites on the apical, nonstereociliary surface of the hair cell. Any receptors on the stereociliary surface will therefore have to migrate down the stereocilia before they can be internalized. However, the polarity of actin filaments in the stereocilia, with their barbed ends at the distal tips (Flock and Cheung, 1977), means that any actindependent movement of myosin molecules with their associated cargo will be directed toward the tip of the stereocilium rather than its base. Therefore, myosin VIIA could not be directly responsible for translocating aminoglycoside receptors from the stereociliary surface to the coated pits, but the continuous upward flow of myosin VIIA-associated molecules along the actin in the 

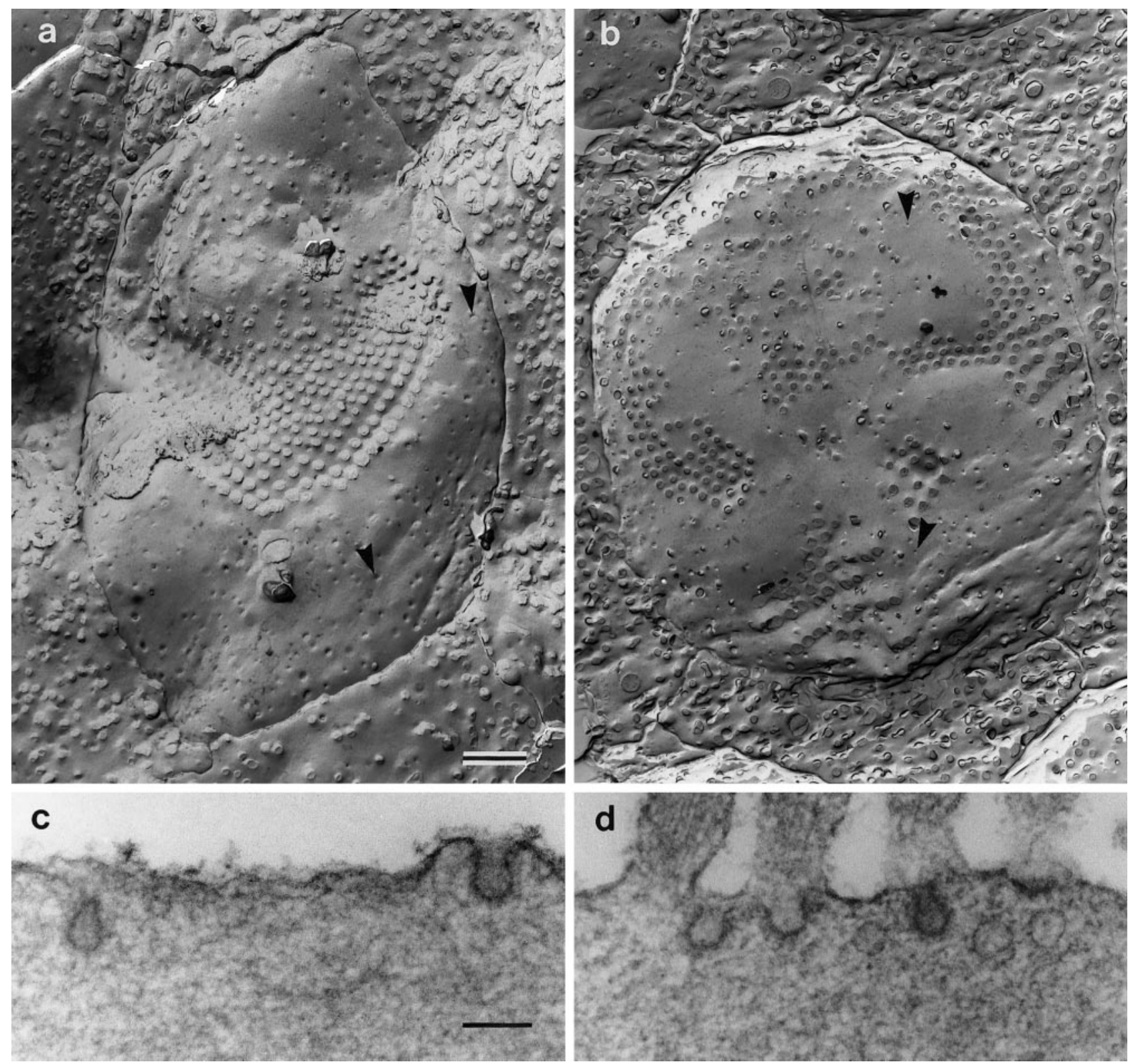

Figure 8. $(a, b)$ Freeze fracture replicas of the apical surface of outer hair cells in cultures prepared from heterozygous $(a)$ and homozygous $(b)$ Myo $7 a^{6 J}$ mice. The arrowheads in $a$ and $b$ point to invaginations of the apical surface corresponding to sites of coated vesicle formation. Scale bar, $1 \mu \mathrm{m}$. $c$, $d$, Transmission electron micrographs illustrating examples of coated pits present on the apical surfaces of outer hair cells in cultures prepared from heterozygous $(c)$ and homozygous $(d) M y o 7 a^{b J}$ mice. Scale bar, $0.1 \mu \mathrm{m}$.

Table 1. Numbers of endocytotic pits per apical profile, areas of the apical profiles, and density of endocytotic pits per unit area of apical membrane for basal-coil outer hair cells in $M y o 7 a^{6 J}$ cultures

\begin{tabular}{|c|c|c|c|}
\hline & $\begin{array}{l}\text { Pits/apical } \\
\text { profile }\end{array}$ & $\begin{array}{l}\text { Apical profile } \\
\text { area }\left(\mu \mathrm{m}^{2}\right)\end{array}$ & Pits $/ \mu \mathrm{m}^{2}$ \\
\hline$+/ M y o 7 a^{6 J}(n=29)$ & $102 \pm 42$ & $38 \pm 10$ & $2.7 \pm 0.8$ \\
\hline Myo $7 a^{6 J} /{\text { Myo } 7 a^{6 J}(n=25)}^{6}$ & $97 \pm 25$ & $46 \pm 9^{*}$ & $2.2 \pm 0.6^{*}$ \\
\hline
\end{tabular}

Values are mean $\pm \mathrm{SD}$.

*Significantly different from value for heterozygotes ( $p<0.01$ in a two-sided $t$ test).

stereocilia may indirectly displace aminoglycoside receptors from the surfaces of stereocilia to coated pits around their bases. In this case both actin and myosin VIIA would be required for endocytosis of aminoglycosides in hair cells. Actin polarity in brush borders is the same as that in stereocilia, and coated pits are restricted to the bases of the microvilli. It is therefore of interest to note that actin is required for apical but not basolateral surface-associated endocytosis in polarized epithelia (Gottlieb et al., 1993; Jackman et al., 1994) and that, in intestinally derived Caco- 2 cells, the actin-disrupting agent cytochalasin D blocks the movement of ricin receptors along the surface of microvilli toward the cell body (Shurety et al., 1996).

Third, myosin VIIA may be required to retain the putative aminoglycoside receptor in the endocytotic pathway once it has been internalized. The aminoglycosides may interact with a receptor that, in the absence of sufficient myosin VIIA or the presence of a nonfunctional molecule, is continuously and rapidly recycled to the plasma membrane rather than being retained in the early to late endosomal pathway. There would be rapid clearance of the 

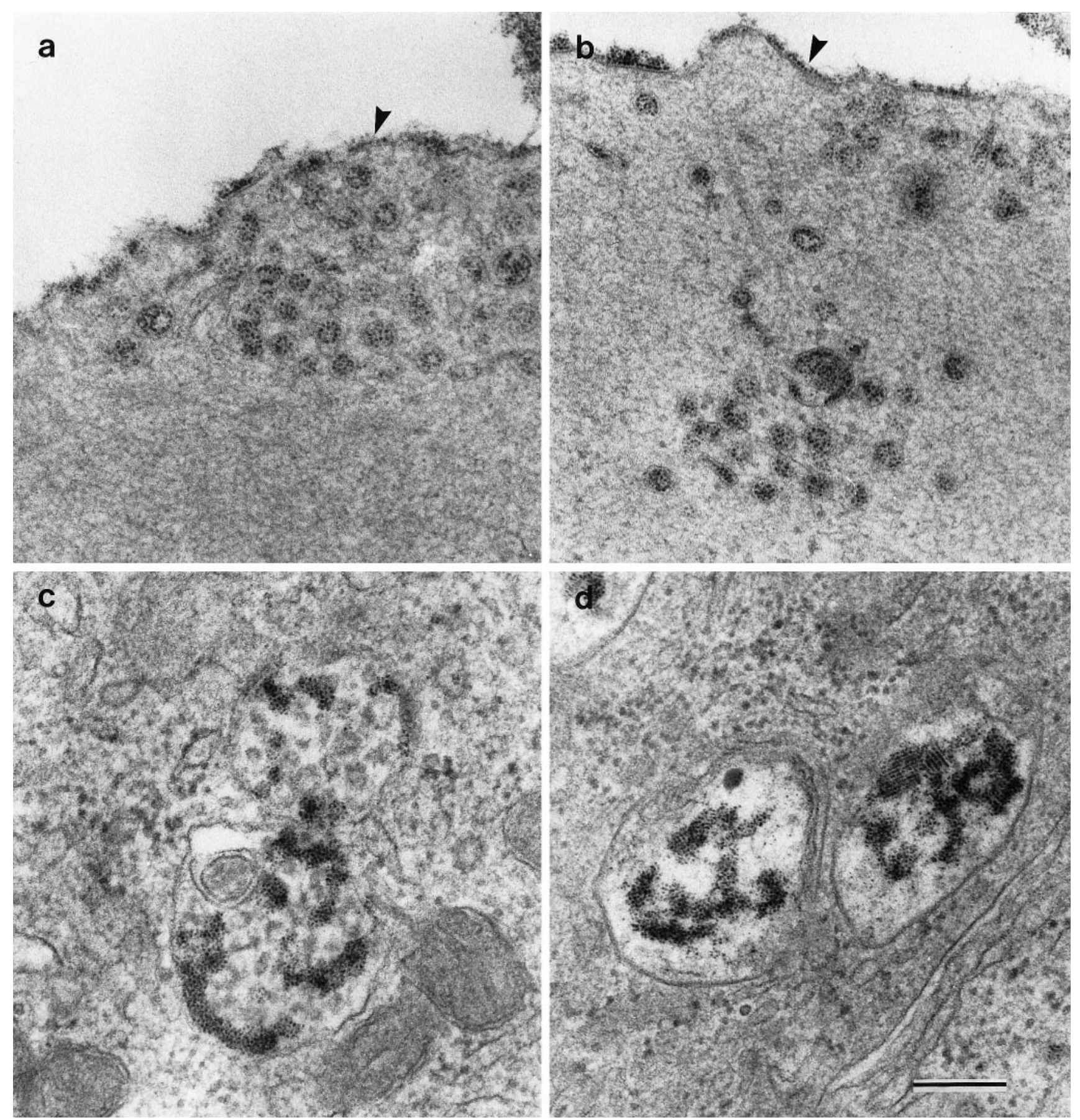

Figure 9. Transmission electron micrographs illustrating examples of cationic ferritin-labeled tubular and vesicular profiles $(a, b)$ and multivesicular bodies $(c, d)$ in outer hair cells from cultures prepared from heterozygous $(a, c)$ and homozygous $(b, d) M y o 7 a^{6 J}$ mice. The arrowheads in $a$ indicate the apical membrane of the outer hair cell. Scale bar, $0.1 \mu \mathrm{m}$.

drug from the cells and no accumulation of aminoglycosides. In this respect it is interesting to note that the apical surfaces of the homozygous $\mathrm{Myo}^{\mathrm{GJ}}$ hair cells in vitro are significantly larger than those in heterozygous controls (Table 1). This could be attributable to an imbalance in some aspect of the apical membrane importexport system, with too much re-export of membrane to the surface accounting for the observed increase in area. A lack of regulated membrane turnover in the homozygous $M y o 7 a^{6 J}$ mutants could also account for the observed disorganization of the hair bundles.
In conclusion, the results of this study demonstrate a role for myosin VIIA in aminoglycoside accumulation and suggest that it may transport a putative aminoglycoside receptor to the apical surface of the hair cell, indirectly translocate it down the stereociliary membrane to sites of membrane retrieval, or retain it in the early to late endosomal pathway. These functions would all be consistent with the predicted structure of the myosin VIIA tail, and therefore it will be interesting to identify the molecules with which this domain interacts. 

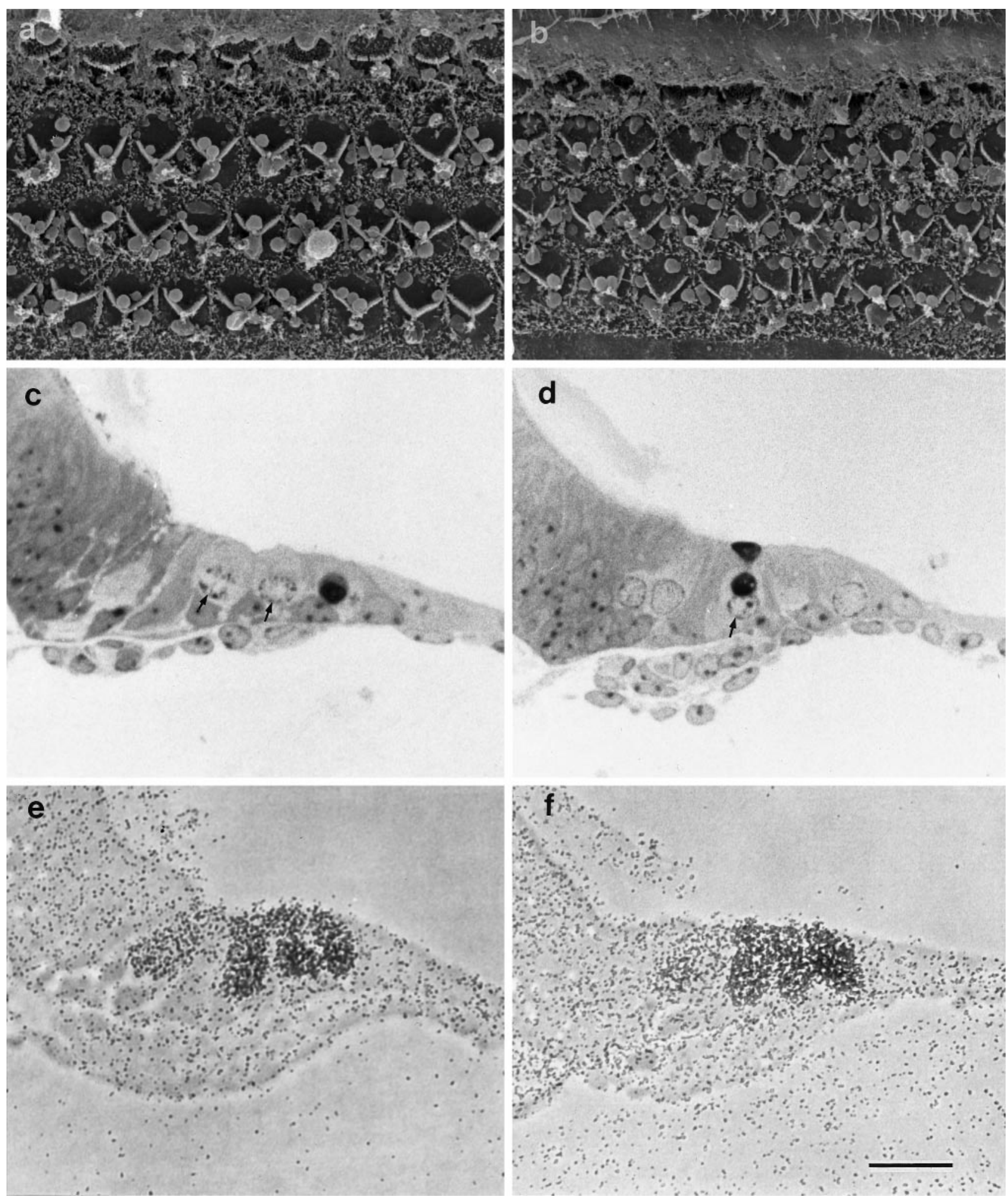

Figure 10. $a, b$ Scanning electron micrographs showing the apical surface of cultures from heterozygous $(a)$ and homozygous $(b) M y o 7 a^{\text {shI }}$ mice after treatment with $1 \mathrm{~mm}$ neomycin for $1 \mathrm{hr}$ at room temperature. $c, d$, Toluidine blue-stained semithin sections of cultures prepared from heterozygous (c) and homozygous $(d) M y o 7 a^{\text {shl } 1}$ mice that have been treated with $2 \mathrm{~mm}$ gentamicin sulfate for $2 \mathrm{hr}$ at $37^{\circ} \mathrm{C}$. The small arrows point to nuclei with condensed chromatin. $e, f$, Autoradiographs of cultures from heterozygous $(e)$ and homozygous $(f) M y o 7 a^{s h 1}$ mice that have been labeled with 0.1 mm $\left[{ }^{3} \mathrm{H}\right]$ gentamicin for $2 \mathrm{hr}$ at $37^{\circ} \mathrm{C}$. Scale bars: $a, b, 10 \mu \mathrm{m}: c-f, 50 \mu \mathrm{m}$.

\section{REFERENCES}

Avraham KB, Hasson T, Steel KP, Kingsley DM, Russell LB, Mooseker MS, Copeland NG, Jenkins NA (1995) The mouse Snell's waltzer deafness gene encodes an unconventional myosin required for the structural integrity of inner ear hair cells. Nat Genet 11:369-375. Beauchamp D, Gourde P, Bergeron MG (1991) Subcellular distribution 
of gentamicin in proximal tubular cells, determined by immunogold labelling. Antimicrob Agents Chemother 35:2173-2179.

Cojecel C, Hook JB (1983) Aminoglycoside nephrotoxicity. Trends Pharmacol Sci 4:174-179.

Chen Z-Y, Hasson T, Kelley PM, Schwender BJ, Schwartz MF, Ramakrishnan M, Kimberling WJ, Mooseker MS, Corey DP (1996) Molecular cloning and domain structure of human myosin-V IIA, the gene product defective in Usher syndrome 1B. Genomics 36:440-448.

Darrouzet J, Guilhaume A (1974) Ototoxicité de la kanamycine au jour le jour. Etude experimentale en microscopie électronique. Rev Laryngol Otol Rhinol (Bord) 95:601-621.

de Groot JCMJ, Meeuwesen F, Ruizendaal WE, Veldman JE (1990) Ultrastructural localisation of gentamicin in the cochlea. Hear Res 50:35-42.

Durrbach A, Collins K, Matsudaira P, Louvard D, Coudrier E (1996) Brush border myosin-I truncated in the motor domain impairs the distribution and function of endocytotic compartments in a hepatoma cell line. Proc Natl Acad Sci USA 93:7053-7058.

El-Amraoui A, Sahly I, Picaud S, Sahel J, Abitol M, Petit C (1996) Human Usher 1B/mouse shaker-1: the retinal phenotype discrepancy explained by the presence/absence of myosin VIIA in the photoreceptor cells. Hum Mol Genet 5:1171-1178.

Flock $\AA$, Cheung HC (1977) Actin filaments in sensory hairs of inner ear receptor cells. J Cell Biol 75:339-343.

Forge A (1985) Outer hair cell loss and supporting cell expansion following chronic gentamicin treatment. Hear Res 19:171-182.

Forge A (1991) Structural features of the lateral walls in mammalian cochlear outer hair cells. Cell Tissue Res 265:473-483.

Forge A, Richardson G (1993) Freeze fracture analysis of apical membranes in cochlear cultures: differences between basal and apical-coil outer hair cells and effects of neomycin. J Neurocytol 22:854-867.

Géléoc GSG, Lennan GWT, Richardson GP, Kros CJ (1997) A quantitative comparison of mechanoelectrical transduction in vestibular and auditory hair cells of neonatal mice. Proc R Soc Lond [Biol] 264:611-621.

Geli MI, Reizman H (1996) Role of type I myosins in receptor-mediated endocytosis in yeast. Science 272:533-535.

Gibson F, Walsh J, Mburu P, Varela A, Brown KA, Antonio M, Beisel KW, Steel KP, Brown SDM (1995) A type VII myosin encoded by the mouse deafness gene shaker-1. Nature 374:62-64.

Gillespie PG, Hudspeth AJ (1993) Adenine nucleoside diphosphate blocks adaptation of mechanoelectrical transduction in hair cells. Proc Natl Acad Sci USA 90:2710-2714.

Gillespie PG, Wagner MC, Hudspeth AJ (1993) Identification of a 120 $\mathrm{kDa}$ hair-bundle myosin I located near stereociliary tips. Neuron 11:581-594.

Gottlieb TA, Ivanov IE, Adensik M, Sabatini DD (1993) Actin filaments play a critical role in endocytosis at the apical but not the basolateral surface of polarized epithelial cells. J Cell Biol 120:695-710.

Hansen SH, Sandvig K, van Deurs B (1991) The preendosomal compartment comprises distinct coated and noncoated endocytotic vesicle populations. J Cell Biol 113:731-741.

Hashino E, Shero M (1995) Endocytosis of aminoglycoside antibiotics in sensory hair cells. Brain Res 704:135-140.

Hasson T, Mooseker M (1994) Porcine myosin-VI: characterization of a new mammalian unconventional myosin. J Cell Biol 127:425-440.

Hasson T, Heinzelman MB, Santos-Sacchi J, Corey DP, Mooseker MS (1995) Expression in cochlea and retina of myosin VIIa, the gene product defective in Usher syndrome type 1B. Proc Natl Acad Sci USA 92:9815-9819.

Hasson T, Gillespie PG, Garcia JA, MacDonald RB, Zhao Y, Yee AG, Mooseker MS, Corey DP (1997a) Unconventional myosins in innerear sensory epithelia. J Cell Biol 137:1287-1307.

Hasson T, Walsh J, Cable J, Mooseker MS, Brown SDM, Steel KP (1997b) Effects of shaker-1 mutations on myosin-VIIA protein and mRNA expression. Cell Motil Cytoskel 37:127-138.

Hawkins Jr JE (1976) Drug ototoxicity. In: Handbook of sensory physiology, Vol 5 (Keidel SD, Neff WD, eds) pp 707-748. New York: Springer.

Hiel H, Schamel A, Erre J-P, Hayashida T, Dulon D, Aran J-M (1992) Cellular and subcellular localisation of tritiated gentamicin in the guinea pig cochlea following combined treatment with ethacrynic acid. Hear Res 57:157-165.

Hille B (1992) Ionic channels of excitable membranes, Ed 2. Sunderland, MA: Sinauer.
Holton T, Hudspeth AJ (1986) The transduction channel of hair cells from the bull-frog characterized by noise analysis. J Physiol (Lond) 375:195-227.

Jaeger RG, Fex J, Kachar B (1994) Structural basis for mechanotransduction in the frog vestibular sensory apparatus: II. The role of microtubules in the organisation of the cuticular plate. Hear Res 77:207-215.

Jackman MR, Shurety W, Ellis JA, Luzio JP (1994) Inhibition of apical but not basolateral endocytosis of ricin and folate in Caco-2 cells by cytochalasin D. J Cell Sci 107:2547-2556.

Jung G, Wu X, Hammer III JA (1996) Dictyostelium mutants lacking multiple classic myosin I isoforms reveal combinations of shared and distinct functions. J Cell Biol 133:305-323.

Kaloyanides GJ, Pastoriza-Munoz E (1980) Aminoglycoside nephrotoxicity. Kidney Int 18:571-582.

Kössl M, Richardson GP, Russell IJ (1990) Stereocilia bundle stiffness: effects of neomycin, A23187 and Concanavalin A. Hear Res 44:217-230.

Kotecha B, Richardson GP (1994) Ototoxicity in vitro: effects of neomycin, gentamicin, dihydrostreptomycin, amikacin, spectinomycin, neamine, spermine and poly-L-lysine. Hear Res 73:173-184.

Kroese ABA, van den Berken J (1980) Dual action of ototoxic antibiotics on sensory hair cells. Nature 283:395-397.

Kroese AB, Das AM, Hudspeth AJ (1989) Blockage of the transduction channels of hair cells in the bullfrog's sacculus by aminoglycoside antibiotics. Hear Res 37:203-217.

Kros CJ, Rüsch A, Richardson GP (1992) Mechano-electrical transducer currents in hair cells of the cultured neonatal mouse cochlea. Proc R Soc Lond [Biol] 249:185-193.

Lamaze C, Schmid SL (1995) The emergence of clathrin-independent pinocytotic pathways. Curr Opin Cell Biol 7:573-580.

Letts VA, Gervais JLM, Frankel WN (1994) Remutation at the shaker-1 locus. Mouse Genome 92:116.

Li L, Nevill G, Forge A (1995) Two modes of hair cell loss from the vestibular sensory epithelia of the guinea pig inner ear. J Comp Neurol 355:405-417.

Mburu P, Liu X, Walsh J, Saw Jr D, Cope MJ TV, Gibson F, KendrickJones J, Steel KP, Brown SDM (1977) Mutation analysis of the mouse myosin VIIa deafness gene. Genes Function 1:191-203.

Mellman I (1996) Endocytosis and molecular sorting. Annu Rev Cell Dev Biol 12:575-625.

Metcalf AB, Chelliah Y, Hudspeth AJ (1994) Molecular cloning of a myosin $1 \beta$ isozyme that may mediate adaptation by hair cells of the bullfrog's internal ear. Proc Natl Acad Sci USA 91:11821-11825.

Mooseker MS, Cheney RE (1995) Unconventional myosins. Annu Rev Cell Dev Biol 11:633-675.

Moore WJ (1972) Physical chemistry, Ed 5. Singapore: Longman.

Novak KD, Peterson MD, Reedy MC, Titus MA (1995) Dictyostelium myosin I double mutants exhibit conditional defects in pinocytosis. J Cell Biol 131:1205-1221.

Richardson GP, Russell IJ (1991) Cochlear cultures as a model system for studying aminoglycoside induced ototoxicity. Hear Res 53:293-311.

Russell IJ, Richardson GP (1987) The morphology and physiology of hair cells in organotypic cultures of the mouse cochlea. Hear Res 31:9-24.

Sandvig K, van Deurs B (1994) Endocytosis without clathrin. Trends Cell Biol 4:275-277.

Shurety W, Bright NA, Luzio JP (1996) The effects of cytochalasin D and phorbol myristate acetate on the apical endocytosis of ricin in polarised Caco-2 cells. J Cell Sci 109:2927-2935.

Silverblatt FJ (1982) Autoradiographic studies of intracellular aminoglycoside disposition in the kidney. In: The aminoglycosides. Microbiology, clinical use, and toxicology (Whelton A, Neu HC, eds), pp 223233. New York: Dekker.

Silverblatt FJ, Kuehn C (1979) Autoradiography of gentamicin uptake by the rat proximal tubule cell. Kidney Int 15:335-345.

Solc CF, Durfler RH, Duyk GM, Corey DP (1994) Molecular cloning of myosins from the bullfrog saccular macula: a candidate for the hair cell adaptation motor. Aud Neurosci 1:63-75.

Steyger PS, Furness DN, Hackney CM, Richardson GP (1989) Tubulin and microtubules in cochlear hair cells: comparative immunocytochemistry and ultrastructure. Hear Res 42:1-16.

Subtil A, Hémar A, Dautry-Varsat A (1994) Rapid endocytosis of interleukin 2 receptors when clathrin-coated pit endocytosis is inhibited. J Cell Sci 107:3461-3468. 
Titus MA (1997) Unconventional myosins: new frontiers in actin-based motors. Trends Cell Biol 7:119-123.

Walker RG, Hudspeth AJ (1996) Calmodulin controls adaptation of mechanoelectrical transduction by hair cells of the bullfrog's sacculus. Proc Natl Acad Sci USA 93:2203-2207.

Weil D, Blanchard S, Kaplan J, Guilford P, Gibson F, Walsh J, Mburu P, Varela A, Levilliers J, Weston MD, Kelley PM, Kimberling WJ, Wagenar M, Levi-Acobas F, Larget-Piet D, Munnich A, Steel KP, Brown SDM, Petit C (1995) Defective myosin VIIA gene responsible for Usher syndrome type 1B. Nature 374:60-61.

Weil D, Levy G, Sahly I, Levi-Acobas F, Blanchard S, El-Amraoui A, Crozet F, Philippe H, Abitbol M, Petit C (1996) Human myosin VIIA responsible for the Usher 1B syndrome: a predicted membraneassociated motor protein expressed in developing sensory epithelia. Proc Natl Acad Sci USA 93:3232-3237.

Wersäll J, Flock Å (1964) Suppression and restoration of the microphonic output from the lateral line organ after local application of streptomycin. Life Sci 3:1151-1155.

Williams SE, Smith DE, Schacht J (1987) Characteristics of gentamicin uptake in the crista ampullaris of the inner ear of the guinea pig. Biochem Pharmacol 36:89-95.

Yamoah EN, Gillespie PG (1996) Phosphate analogs block adaptation in hair cells by inhibiting adaptation-motor force production. Neuron 17:523-533. 